\title{
Effect of Ni-P Plating Temperature on Growth of Interfacial Intermetallic Compound in Electroless Nickel Immersion Gold/Sn-Ag-Cu Solder Joints
}

\author{
WONIL SEO, ${ }^{1,2}$ KYOUNG-HO KIM, ${ }^{1}$ YOUNG-HO KIM, $, 2,3$ \\ and SEHOON YOO (iD) \\ 1.-Joining R\&D Group, Korea Institute of Industrial Technology, Incheon 406-840, \\ Korea. 2.-Division of Materials Science and Engineering, Hanyang University, Seoul, \\ Korea. 3.—e-mail: kimyh@hanyang.ac.kr. 4.—e-mail: yoos@kitech.re.kr
}

The growth of interfacial intermetallic compound and the brittle fracture behavior of Sn-3.0Ag-0.5-Cu solder (SAC305) joints on electroless nickel immersion gold (ENIG) surface finish have been investigated using Ni-P plating solution at temperatures from $75^{\circ} \mathrm{C}$ to $85^{\circ} \mathrm{C}$ and fixed $\mathrm{pH}$ of 4.5 . SAC305 solder balls with diameter of $450 \mu \mathrm{m}$ were mounted on the prepared ENIG-finished $\mathrm{Cu}$ pads and reflowed with peak temperature of $250^{\circ} \mathrm{C}$. The interfacial intermetallic compound (IMC) thickness after reflow decreased with increasing Ni-P plating temperature. After $800 \mathrm{~h}$ of thermal aging, the IMC thickness of the sample prepared at $85^{\circ} \mathrm{C}$ was higher than for that prepared at $75^{\circ} \mathrm{C}$. Scanning electron microscopy of the Ni-P surface after removal of the Au layer revealed a nodular structure on the Ni-P surface. The nodule size of the Ni-P decreased with increasing Ni-P plating temperature. The $\mathrm{Cu}$ content near the IMC layer increased to $0.6 \mathrm{wt} . \%$, higher than the original $\mathrm{Cu}$ content of $0.5 \mathrm{wt} . \%$, indicating that $\mathrm{Cu}$ diffused from the $\mathrm{Cu}$ pad to the solder ball through the Ni-P layer at a rate depending on the nodule size. The sample prepared at $75^{\circ} \mathrm{C}$ with thicker interfacial IMC showed greater high-speed shear strength than the sample prepared at $85^{\circ} \mathrm{C}$. Brittle fracture increased with decreasing Ni-P plating temperature.

Key words: Electroless nickel immersion gold, Sn-3.0Ag-0.5Cu, Ni-P, plating temperature, interfacial intermetallic compound, brittle fracture, high-speed shear strength

\section{INTRODUCTION}

Surface finishing with electroless nickel immersion gold (ENIG) offers the advantages of excellent solderability, high corrosion resistance, uniform thickness, and selective deposition. ${ }^{1-3}$ During reflow soldering, the Au layer of ENIG dissolves into the molten solder, exposing the underlying $\mathrm{Ni}-\mathrm{P}$ layer to the molten solder. Thereafter, $\mathrm{Ni}, \mathrm{Sn}$, and $\mathrm{Cu}$ react to form interfacial intermetallic compounds (IMCs), either $(\mathrm{Cu}, \mathrm{Ni})_{6} \mathrm{Sn}_{5}$ or $(\mathrm{Ni}, \mathrm{Cu})_{3} \mathrm{Sn}_{4}$ depending on the

(Received April 25, 2017; accepted September 19, 2017; published online October 4, 2017)
$\mathrm{Cu}$ content in the $\mathrm{Sn}-\mathrm{Ag}-\mathrm{Cu}$ (SAC) solder. $^{4}$ In addition, Ni-Sn-P with nanovoids and P-rich layers also form between the interfacial IMC and Ni-P layer. ${ }^{5-7}$ Such interfacial layers are brittle in nature, thus properties of the solder joint depend on these interfacial microstructures. ${ }^{8,9}$

The properties of the Ni-P layer are important to obtain sound solder joints, since the interfacial microstructures after reflow soldering are formed from the Ni-P layer and solder. Many studies on the Ni-P layer have investigated the effect of the phosphorus content on the solder joint. ${ }^{10-12}$ The $\mathrm{P}$ content in the Ni-P layer affects the interfacial IMC thickness, joint strength, and solder wettability. ${ }^{10-12}$ These properties of the Ni-P layer depend 

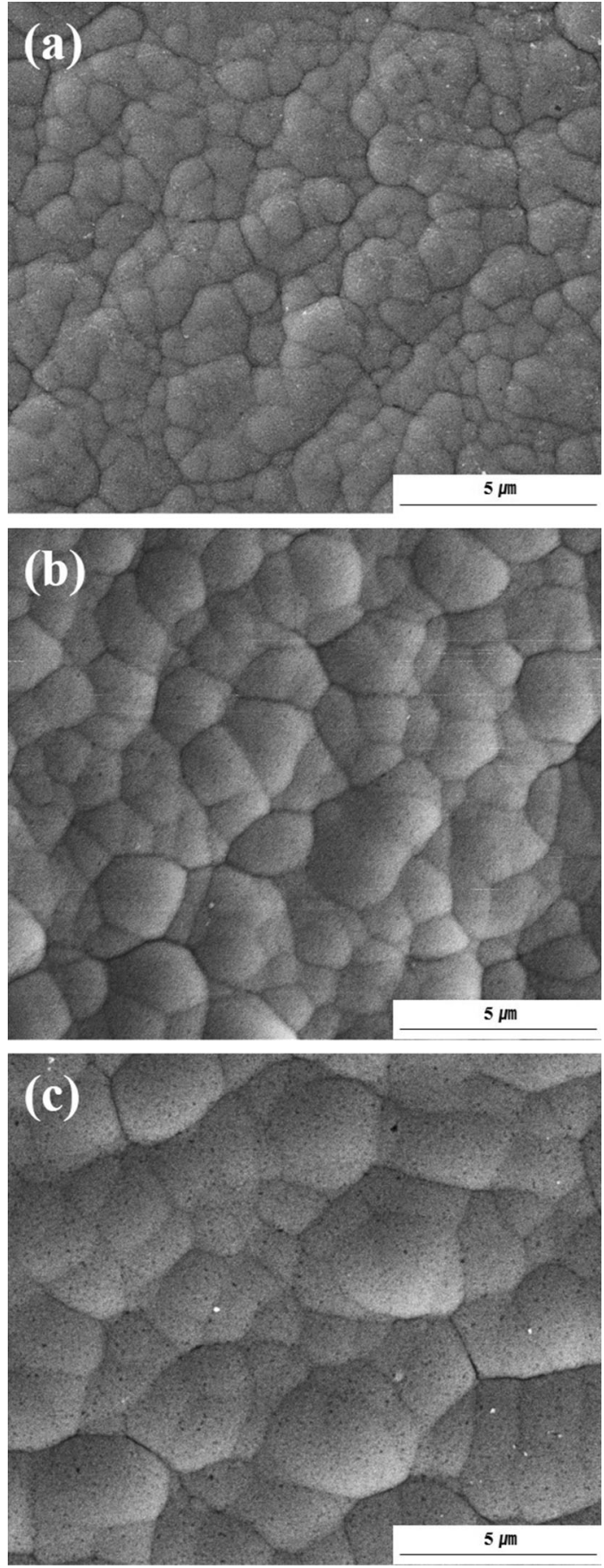

Fig. 1. Surface morphology of electroless plated Ni-P layer deposited at temperature of (a) $75^{\circ} \mathrm{C}$, (b) $80^{\circ} \mathrm{C}$, and (c) $85^{\circ} \mathrm{C}$.

on the Ni-P electroless plating conditions, including temperature, $\mathrm{pH}$, additives, etc. Hence, the effects of these conditions on the properties of the Ni-P layer and the solder joint must be evaluated. In case of $\mathrm{Cu}$-solder reaction, many studies have reported that $\mathrm{Cu}$ plating conditions such as additives are related to microvoid formation at the $\mathrm{Cu}-$ $\mathrm{Cu}_{3} \mathrm{Sn}$ interface, affecting the final solder joint reliability. ${ }^{13-17}$ In case of $\mathrm{Ni}$-solder reaction, it is reported that the Ni-P plating bath life affects the brittle fracture behavior of $\mathrm{Sn}-\mathrm{Ag}-\mathrm{Cu}$ solder joints. ${ }^{18}$ However, few studies have investigated the effect of Ni-P plating conditions on solder joint properties.

The aim of this study is to understand the effect of the Ni-P plating temperature on the interfacial IMC formation and the brittle fracture behavior of the solder joint. Ni-P plating temperatures of $75^{\circ} \mathrm{C}$, $80^{\circ} \mathrm{C}$, and $85^{\circ} \mathrm{C}$ were investigated, with fixed $\mathrm{pH}$ of 4.5. The thickness of the Ni-P layer was also fixed at $2 \mu \mathrm{m}$ to exclude the effect of the Ni-P thickness on diffusion. The brittle fracture behavior was determined by high-speed shear (HSS) testing. In addition, the fracture surface was observed by fieldemission scanning electron microscopy (FE-SEM) to determine the fracture mode.

\section{EXPERIMENTAL PROCEDURES}

The test printed circuit board (PCB) used in this study was solder mask defined (SMD)-type FR-4 board. The $\mathrm{Cu}$ pad diameter and thickness on the test PCB were $400 \mu \mathrm{m}$ and $10 \mu \mathrm{m}$, respectively. The thickness of photoimageable solder resist (PSR) on the test PCB was $15 \mu \mathrm{m}$. The $\mathrm{pH}$ of the Ni-P electroless plating bath was fixed at 4.5 , while the temperature was $75^{\circ} \mathrm{C}, 80^{\circ} \mathrm{C}$, or $85^{\circ} \mathrm{C}$. The thickness of the electroless Ni-P was $2 \mu \mathrm{m}$, and the plating time was $45 \mathrm{~min}, 27 \mathrm{~min}$, and $18 \mathrm{~min}$ for the $75^{\circ} \mathrm{C}$, $80^{\circ} \mathrm{C}$, and $85^{\circ} \mathrm{C}$ condition, respectively. After Ni-P electroless plating, Au was deposited by immersion plating. The $\mathrm{pH}$ of the immersion $\mathrm{Au}$ bath was 5.9, and the plating time for immersion $\mathrm{Au}$ was $10 \mathrm{~min}$. The thickness of the Au was $0.05 \mu \mathrm{m}$.

To attach a solder ball onto the ENIG surface finish, Sn-3.0 wt.\%Ag-0.5 wt.\%Cu (SAC305) solder paste (M705-SHF, Senju) was printed onto the ENIG-finished $\mathrm{Cu}$ pads. Then, a SAC305 solder ball (ET16E02P, Ducsan Hi-Metal) was attached to the printed solder paste. The SAC305 solder ball was then reflowed with peak temperature of $250^{\circ} \mathrm{C}$.

Interfacial IMC was observed by scanning electron microscopy (SEM, Inspect F, FEI) on samples epoxy-mounted and polished using $\mathrm{SiC}$ papers then finely polished with alumina suspension. Then, $\mathrm{Pt}$ was deposited onto the polished surface using a sputter (SCD005, Leica) for SEM observation. For surface morphology observation of the Ni-P layer, the immersion $\mathrm{Au}$ layer was removed using $\mathrm{Au}$ etchant (MK Chem \&Tech), after which the surface morphology of the Ni-P was observed by SEM. The nodule size was measured using image analysis software (Image Pro Plus, The Proven Solution). The elemental composition of the IMC layer and the solder inside was analyzed by electron probe $\mathrm{x}$-ray microanalysis (EPMA, JXA-8500F, JEOL) and energy-dispersive spectroscopy (EDS, SuperdryII, Nolan). 
The strength of the reflowed SAC305 solder joint on the ENIG surface finish was measured using a high-speed ball shear tester (Dage, 4000HS) with shear height of $50 \mu \mathrm{m}$ and shear speeds of $0.3 \mathrm{~m} / \mathrm{s}$, $0.5 \mathrm{~m} / \mathrm{s}$, and $1 \mathrm{~m} / \mathrm{s}$. The fracture mode was determined from the fracture surface, being classified into five categories: $100 \%, 75 \%, 50 \%, 25 \%$, and $0 \%$ brittle. The $100 \%$ brittle fracture mode corresponds to the entire area showing brittle fracture, while the $75 \%, 50 \%, 25 \%$, and $0 \%$ brittle fracture categories had corresponding percentages of brittle fracture area of $75 \%$ to $100 \%, 50 \%$ to $75 \%, 25 \%$ to $50 \%$, and $0 \%$ to $25 \%$ on the fracture surface.

\section{RESULTS AND DISCUSSION}

The SEM surface morphology of electroless Ni-P deposited at bath temperature of $75^{\circ} \mathrm{C}, 80^{\circ} \mathrm{C}$, and $85^{\circ} \mathrm{C}$ is shown in Fig. 1. Nodular structure was observed on the surface of the electroless Ni-P layer. The nodule size of the Ni-P increased with increasing electroless plating temperature, as shown in Fig. 2 based on image analysis. The average nodule size of the Ni-P was $0.6 \mu \mathrm{m}, 1.0 \mu \mathrm{m}$, and $1.76 \mu \mathrm{m}$ for the samples prepared at $75^{\circ} \mathrm{C}, 80^{\circ} \mathrm{C}$, and $85^{\circ} \mathrm{C}$, respectively. The average nodule size for the samples prepared at $85^{\circ} \mathrm{C}$ was twice as large as for those prepared at $75^{\circ} \mathrm{C}$. Tsai et al. reported that an electroless Ni-P layer with 5.9 wt.\% phosphorus showed columnar structure according to cross-sectional transmission electron microscopy (TEM)

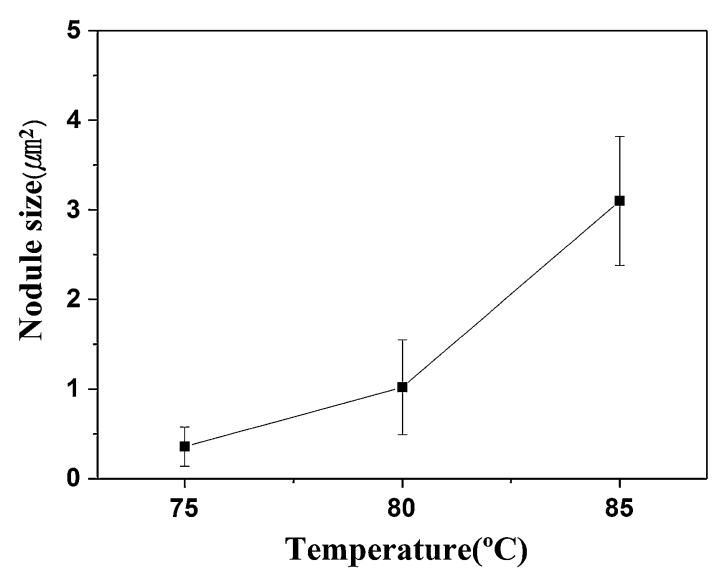

Fig. 2. Variation of Ni-P nodule size with electroless plating temperature.

Table I. P content in electroless Ni-P layer

\begin{tabular}{|c|c|c|}
\hline \multirow{2}{*}{ Plating temperature $\left({ }^{\circ} \mathrm{C}\right)$} & \multicolumn{2}{|c|}{$\begin{array}{c}\text { Composition } \\
\text { (wt.\%) }\end{array}$} \\
\hline & $\mathbf{P}$ & $\mathbf{N i}$ \\
\hline 75 & 9.7 & 80.3 \\
\hline 80 & 9.6 & 80.4 \\
\hline 85 & 9.5 & 80.5 \\
\hline
\end{tabular}

observation. ${ }^{19}$ They also observed columnar structure of Ni-P for 8.6 wt.\% and 11.8 wt.\% phosphorus. ${ }^{19}$ Therefore, the surface nodules observed by SEM in our study correspond to the top of such Ni-P columns and the nodule size is related to the diameter of the Ni-P columns.

The $\mathrm{P}$ content of the electroless Ni-P deposit was determined by EDS and is presented in Table I. The
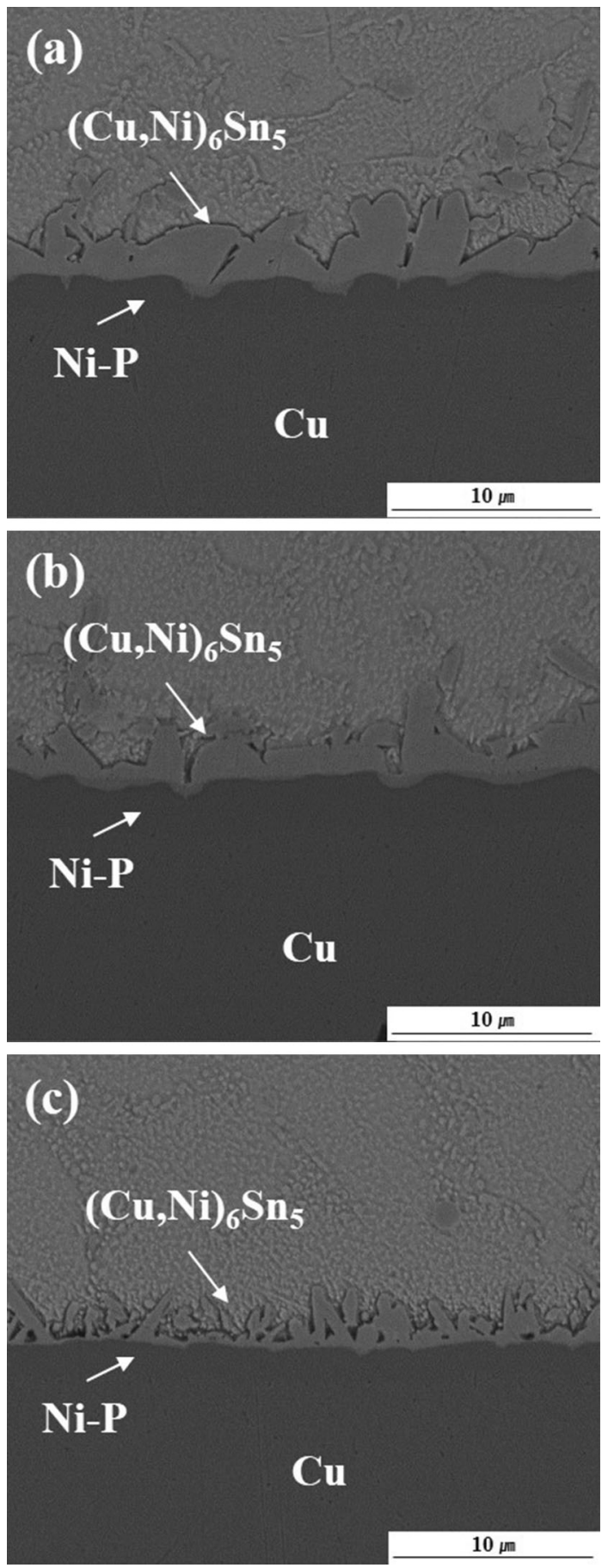

Fig. 3. Cross-sectional SEM micrographs of SAC305 reflowed on ENIG surface finish for Ni-P plating temperature of (a) $75^{\circ} \mathrm{C}$, (b) $80^{\circ} \mathrm{C}$, and (c) $85^{\circ} \mathrm{C}$. 
$\mathrm{P}$ content for the three plating temperature conditions was 9.7 wt.\%, 9.6 wt.\%, and 9.5 wt.\% for the samples prepared at $75^{\circ} \mathrm{C}, 80^{\circ} \mathrm{C}$, and $85^{\circ} \mathrm{C}$, respectively. It is reported that Ni-P is crystalline, crystalline + amorphous, and amorphous for $\mathrm{P}$ content of under $6 \%, 6 \mathrm{wt} . \%$ to $10 \mathrm{wt} . \%$, and over $10 \%$, respectively. ${ }^{20}$ The $\mathrm{P}$ content in this study was 9.5 wt.\% to 9.7 wt.\%, thus the Ni-P layer was expected to possess crystalline + amorphous structure. It is reported that Ni-P nanocrystallites are embedded in an amorphous matrix in case of crystalline + amorphous mixed microstructure. ${ }^{21,22}$ Therefore, the Ni-P layer in this study was expected to have amorphous columnar structure with nanocrystallites.

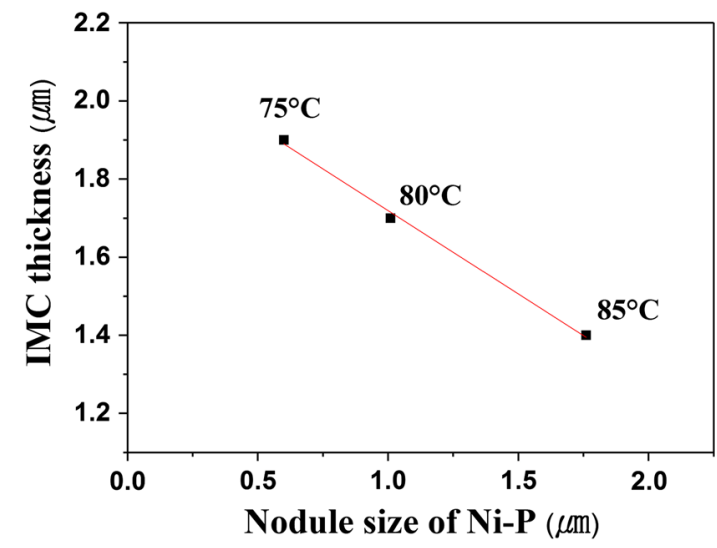

Fig. 4. IMC thickness versus nodule size of Ni-P.
Cross-sectional SEM micrographs of SAC305 solder balls reflowed on ENIG surface finish are shown in Fig. 3 for Ni-P plating temperatures of $75^{\circ} \mathrm{C}$, $80^{\circ} \mathrm{C}$, and $85^{\circ} \mathrm{C}$. The interfacial IMC layer between the Ni-P and SAC305 solder was $(\mathrm{Cu}, \mathrm{Ni})_{6} \mathrm{Sn}_{5}$. The $(\mathrm{Cu}, \mathrm{Ni})_{6} \mathrm{Sn}_{5}$ IMC thickness of the sample prepared at $75^{\circ} \mathrm{C}$ was greater than for those prepared at $80^{\circ} \mathrm{C}$ or $85^{\circ} \mathrm{C}$. The IMC thickness decreased with increasing Ni-P plating temperature.

The relationship between the interfacial IMC thickness and the Ni-P plating temperature appeared to result from the nodule size of the Ni-P layer, which affected the rates of diffusion of elements through the Ni-P layer. In columnar structure, diffusion along column boundaries is faster than through the inside of the column. ${ }^{23}$ Therefore, as the nodule size increased, the total length of the column boundaries decreased and the diffusion rate through the Ni-P also decreased. The relationship between the nodule size and IMC thickness is plotted in Fig. 4. The average IMC thickness of the Ni-P was $1.9 \mu \mathrm{m}, 1.7 \mu \mathrm{m}$, and $1.4 \mu \mathrm{m}$ for samples prepared at $75^{\circ} \mathrm{C}, 80^{\circ} \mathrm{C}$, and $85^{\circ} \mathrm{C}$, respectively. The thickness of the $(\mathrm{Cu}, \mathrm{Ni})_{6} \mathrm{Sn}_{5}$ IMC was negatively linearly related to the nodule size of the Ni-P. The relationship between the IMC thickness and the Ni-P nodule size indicates that fast diffusion along the column boundaries affected the IMC growth.

The upwardly diffusing element for IMC formation is either $\mathrm{Ni}$ or $\mathrm{Cu}$, or both. In this study, the $\mathrm{Cu}$ content near the interface was measured by EPMA to understand the upward diffusion; the results are
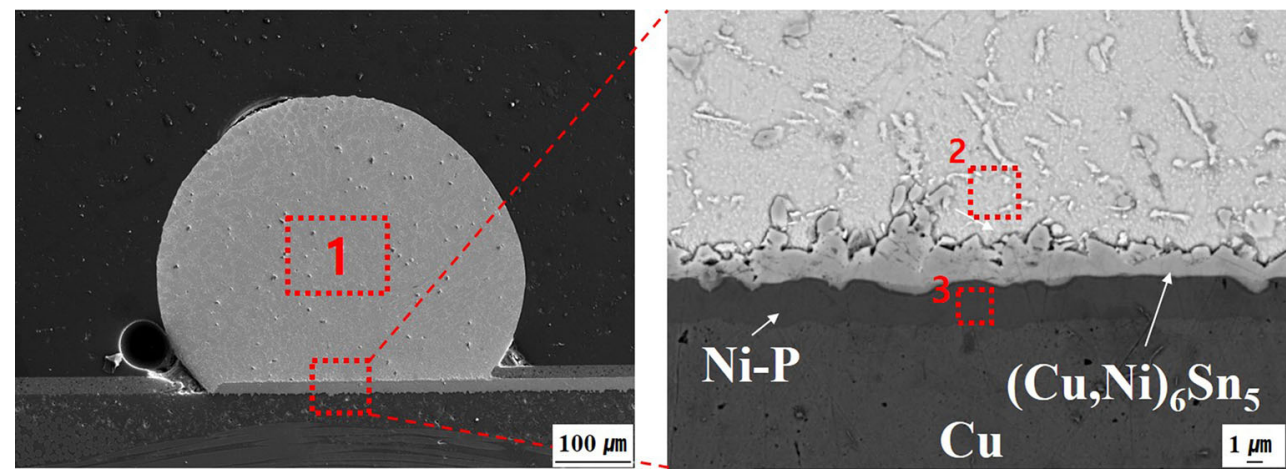

Fig. 5. Cross-sectional EPMA micrographs of SAC305 solder joint.

Table II. Composition of $\mathrm{Cu}, \mathrm{Sn}, \mathrm{Ni}$, and $\mathrm{Ag}$ in the analysis regions of Fig. 5

\begin{tabular}{|c|c|c|c|c|}
\hline \multirow[b]{2}{*}{ Analysis region } & \multicolumn{4}{|c|}{ Composition (wt.\%) } \\
\hline & $\mathbf{C u}$ & Sn & $\mathbf{N i}$ & Ag \\
\hline 1 & 0.6 & 96.02 & 0.07 & 3.31 \\
\hline 2 & 0.77 & 98.60 & 0.38 & 0.23 \\
\hline 3 & 1.75 & 0.7 & 89.19 & 8.34 \\
\hline
\end{tabular}



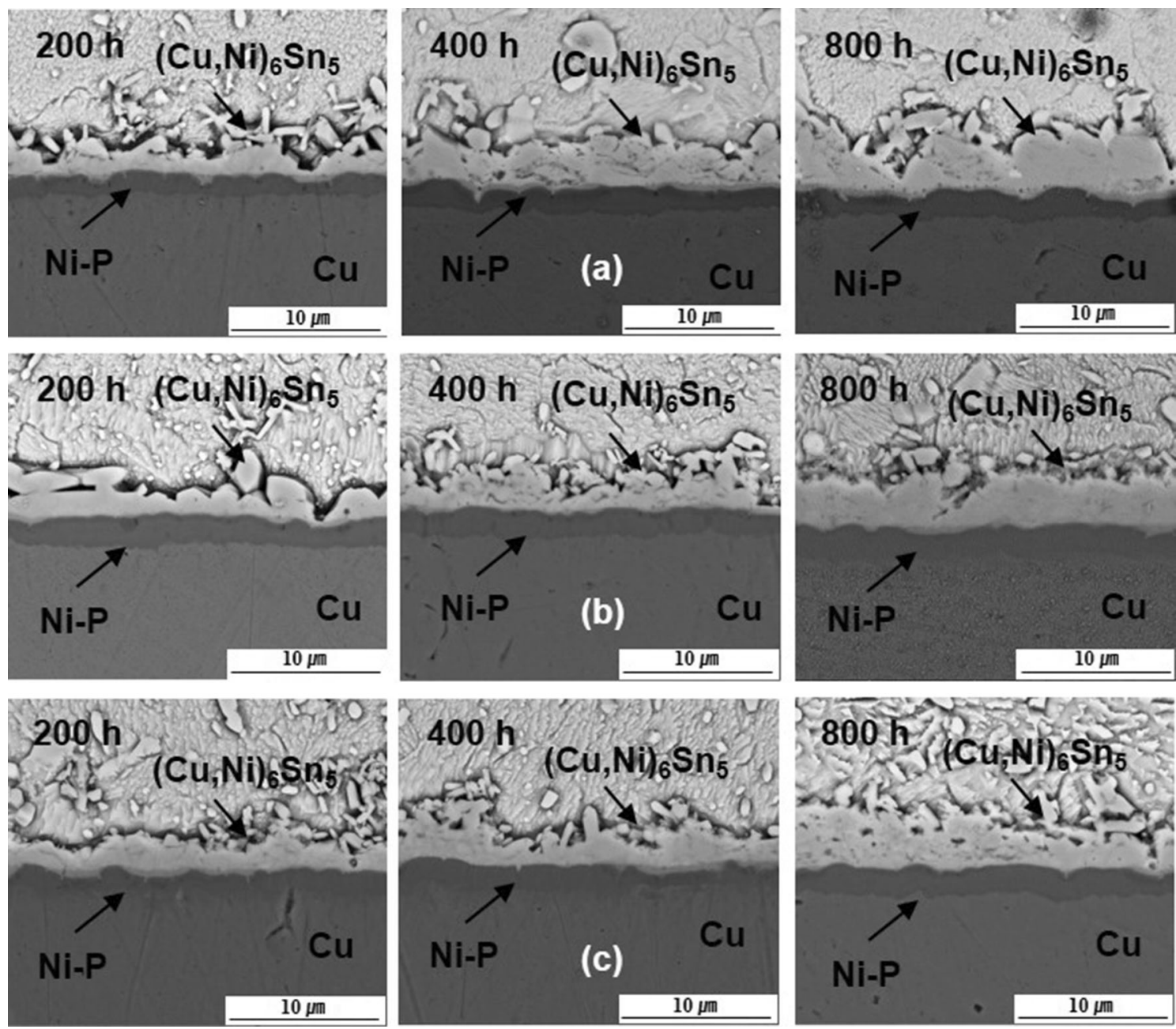

Fig. 6. Interfacial IMC growth with thermal aging for Ni-P plating temperature of (a) $75^{\circ} \mathrm{C}$, (b) $80^{\circ} \mathrm{C}$, and (c) $85^{\circ} \mathrm{C}$.

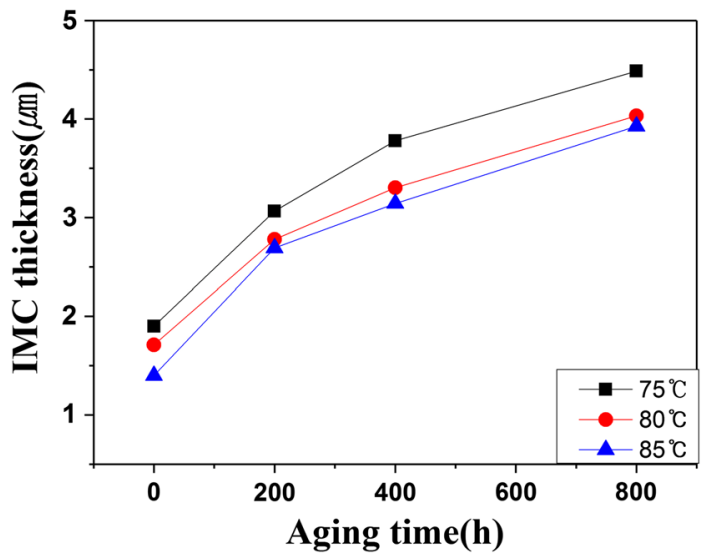

Fig. 7. IMC thickness versus thermal aging time for different $\mathrm{Ni}-\mathrm{P}$ plating temperatures.

shown in Fig. 5 and Table II. After reflow, the $\mathrm{Cu}$ content in the solder (region 1 in Fig. 5) was 0.60 wt.\%, being higher than the original $\mathrm{Cu}$

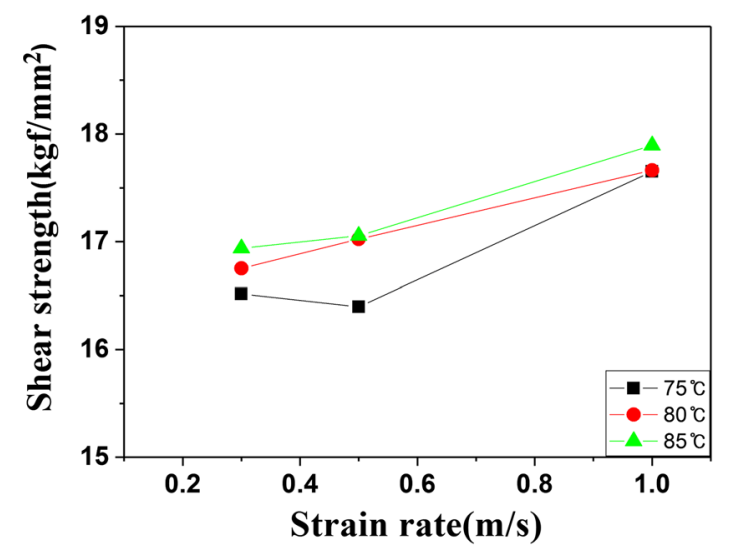

Fig. 8. Shear strength of SAC305 solder joint versus strain rate for different Ni-P plating temperatures.

content (0.5 wt.\%) in SAC305 solder. The $\mathrm{Cu}$ content in the solder near the IMC (region 2) and in the Ni-P layer (region 3) was 0.77 wt.\% and 1.75 wt.\%, 


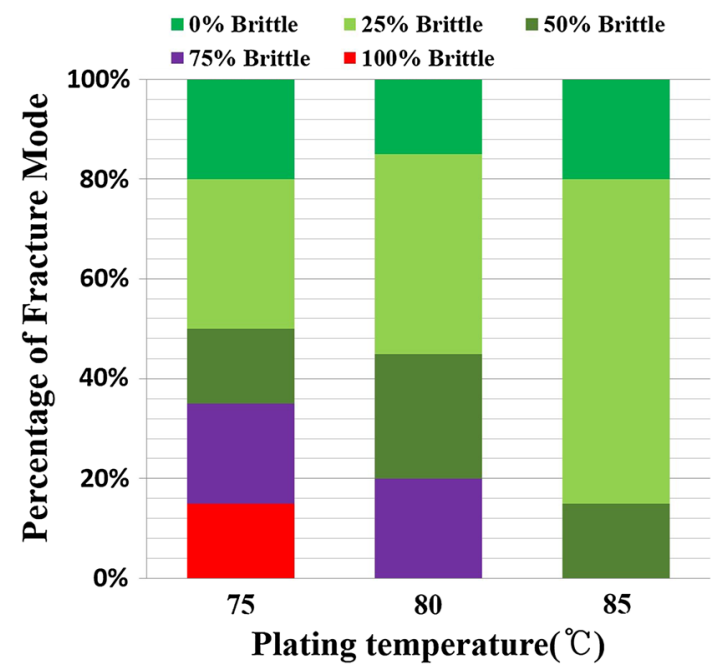

Fig. 9. Brittle fracture percentages for SAC305 solder joints obtained with different Ni-P plating temperatures.

respectively. The number of $\mathrm{Cu}$ atoms in the solder region $\left(N_{\text {cu }}\right)$ was calculated using the equation ${ }^{24}$

$$
N_{\mathrm{Cu}}=\frac{V_{\mathrm{s}} \rho_{\mathrm{S}} N_{\mathrm{A}} n}{M_{\mathrm{Cu}}}-\frac{A t_{\mathrm{I}} \rho_{\mathrm{I}} N_{\mathrm{A}} m}{M_{\mathrm{I}}} p,
$$

where subscripts "s" and "I" indicate solder and IMC, respectively. $V, \rho$, and $M$ represent the volume, density, and molecular (atomic) mass, respectively. $N_{\mathrm{A}}$ is Avogadro's number, $n$ is the weight percent of $\mathrm{Cu}$ in the solder before reaction, $A$ is the area of the solder pad, $t$ is the thickness of the IMC, $m$ is the number of $\mathrm{Cu}(\mathrm{Ni})$ atoms per molecule of IMC, and $p$ is the fraction of $\mathrm{Cu}$ occupying $\mathrm{Cu}(\mathrm{Ni})$ sites of the IMC lattice. The $\mathrm{Cu}$ content in the bulk solder calculated using Eq. 1 was 0.35 wt.\%, being lower than the original $\mathrm{Cu}$ content of 0.5 wt.\%. Since $\mathrm{Cu}$ in SAC305 solder participates in the interfacial IMC layer, the $\mathrm{Cu}$ content should decrease theoretically. However, the EPMA results (Fig. 6) showed that the $\mathrm{Cu}$ content in the solder was 0.6 wt.\%, being higher than the calculated $\mathrm{Cu}$ content $(0.35$ wt.\%). The increase of the $\mathrm{Cu}$ content in the solder after reflow indicates that $\mathrm{Cu}$ diffused from the $\mathrm{Cu}$ pad through the Ni-P layer, at a rate depending on the Ni-P column width.

The interfacial IMC growth during thermal aging was observed by SEM and is shown in Fig. 6. The IMC thickness of the sample prepared at $75^{\circ} \mathrm{C}$ was higher than for the other conditions. The IMC thickness is plotted against aging time in Fig. 7. The relationship between the IMC thickness, $X(t, T)$, and aging time can be represented as follows:

$$
X=X_{0}+D t^{n}
$$

where $X$ is the IMC thickness at time $t, n$ is the time exponent, $X_{0}$ is the IMC layer thickness in asreflowed condition, and $D$ is the average diffusion coefficient for given temperature. Equation 1 can be converted to

$$
\ln \left(X-X_{0}\right)=n \ln D+n \ln t,
$$

where $n$ in Eq. 2 indicates the growth mechanism. If $n$ is 1 , the IMC growth is controlled by the rate of reaction, whereas if $n$ is 0.5 , the IMC growth is controlled by diffusion. If $n$ is 0.33 , the IMC growth is controlled by diffusion accompanied by grain coarsening. ${ }^{25}$ The $n$ values for the samples prepared at $75^{\circ} \mathrm{C}, 80^{\circ} \mathrm{C}$, and $85^{\circ} \mathrm{C}$ were $0.57,0.56$, and 0.48 , respectively. Therefore, the IMC growth was controlled by diffusion. As the plating temperature was increased, the Ni-P column size (or nodule size) decreased and the diffusion rate along the column boundaries decreased. Hence, the IMC thickness was lowest for the sample prepared at $85^{\circ} \mathrm{C}$ with large column size.

The IMC thickness is generally related to the brittle fracture behavior. To understand the relationship between the IMC thickness variation for different Ni-P plating temperatures and the brittle fracture, high-speed shear (HSS) testing was carried out; the results are shown in Fig. 8. The strain rate was varied from $0.3 \mathrm{~m} / \mathrm{s}$ to $1.0 \mathrm{~m} / \mathrm{s}$. The HSS strength of the sample prepared at $85^{\circ} \mathrm{C}$ was higher than for those prepared at $70^{\circ} \mathrm{C}$ or $75^{\circ} \mathrm{C}$, since its IMC thickness was the lowest.

The fracture surface after the HSS test was observed by SEM and the fracture modes determined from the fracture surface, being classified into five fracture modes with $100 \%, 75 \%, 50 \%, 25 \%$, and $0 \%$ brittle fracture. The fracture modes for 25 samples prepared at each plating temperature are shown in Fig. 9. The strain rate was $1 \mathrm{~m} / \mathrm{s}$. For the samples prepared at $75^{\circ} \mathrm{C}, 12 \%$ of the fracture modes were $100 \%$ brittle. For the samples prepared at $80^{\circ} \mathrm{C}$ and $85^{\circ} \mathrm{C}$, the $100 \%$ brittle mode was not observed. For the samples prepared at $85^{\circ} \mathrm{C}$, even the $75 \%$ brittle mode was not observed. As the Ni-P plating temperature was increased, the brittle fracture rate decreased since the IMC thickness decreased.

In summary, the Ni-P nodule size increased and the IMC thickness decreased with increasing Ni-P plating temperature. The decrease of the IMC thickness with increasing plating temperature resulted in low brittle fracture rate. The results of this study show that the Ni-P plating temperature affects the properties of the final solder joint. In addition, this study clarifies the contradictory results of previous studies related to the relationship between the $\mathrm{pH}$ of the Ni-P plating solution and the nodule size of the plated Ni-P layer. Many researchers have reported that increasing the $\mathrm{pH}$ of the Ni-P plating solution increases the nodule size of the Ni-P layer. ${ }^{10,26,27}$ However, Chow et al. ${ }^{28}$ reported that increasing the $\mathrm{pH}$ decreased the nodule size of Ni-P. In fact, their plating temperature was $88^{\circ} \mathrm{C}$ at $\mathrm{pH}$ of 4.8 and $44^{\circ} \mathrm{C}$ at $\mathrm{pH}$ of 8.5 , 
thus Chow et al. decreased the plating temperature when they increased the $\mathrm{pH}$. Therefore, the decrease of the Ni-P nodule size occurred due to the change in plating temperature rather than $\mathrm{pH}$. This example demonstrates that the effect of plating temperature reported herein could be applied to interpret results of other studies. In addition, the relationship between other Ni-P plating parameters such as additives and solder joint properties has not been widely studied; therefore, further study of the effect of plating parameters on solder joint properties is required in the near future.

\section{CONCLUSIONS}

The interfacial IMC thickness and brittle fracture behavior of SAC305 solder on ENIG obtained using different Ni-P plating temperatures were investigated. The Ni-P layer exhibited nodular structure, and the nodule size increased with increasing plating temperature. The thickness of the $(\mathrm{Cu}, \mathrm{Ni})_{6} \mathrm{Sn}_{5}$ IMC layer decreased with increasing $\mathrm{Ni}-\mathrm{P}$ plating temperature. The $\mathrm{Cu}$ content near the IMC layer increased to $0.6 \mathrm{wt} . \%$, being higher than the original $\mathrm{Cu}$ content of 0.5 wt.\%. This increased $\mathrm{Cu}$ content indicates that $\mathrm{Cu}$ diffused from the $\mathrm{Cu}$ pad to the solder ball through the Ni-P layer, at a rate that depended on the nodule size. The shear strength of the sample prepared at $85^{\circ} \mathrm{C}$ was higher than that prepared at $75^{\circ} \mathrm{C}$. In addition, the brittle fracture rate decreased with increasing $\mathrm{Ni}-\mathrm{P}$ plating temperature. In the future, the effect of other Ni-P plating conditions such as additives must be evaluated to obtain highly reliable solder joints on ENIG surface finish.

\section{ACKNOWLEDGEMENTS}

This work was financially supported by a research project from the Ministry of Trade, Industry, and Energy, Republic of Korea.

\section{REFERENCES}

1. R. Aschenbrenner, A. Ostmann, U. Beutler, J. Simon, and H. Reichl, IEEE Trans. Compon. Packag. Manuf. Technol. B 18, 334 (1995).

2. G.O. Mallory and J.B. Hajdu, Electroless Plating: Fundamentals and Applications (New York: William Andrew, 1990).

3. Z. Kejun, V. Vuorinen, and J.K. Kivilahti, IEEE Trans. Electron. Packag. Manuf. 25, 162 (2002).

4. C.E. Ho, R.Y. Tsai, Y.L. Lin, and C.R. Kao, J. Electron. Mater. 31, 584 (2002).

5. Y.-C. Lin, K.-J. Wang, and J.-G. Duh, J. Electron. Mater. 39, 283 (2009).

6. C. Ho, Y. Lin, and C. Kao, Chem. Mater. 14, 949 (2002).

7. M. Alam, Y. Chan, and K. Tu, Chem. Mater. 15, 4340 (2003).

8. K. Zeng and K.-N. Tu, Mater. Sci. Eng. R 38, 55 (2002).

9. T. Laurila, V. Vuorinen, and J.K. Kivilahti, Mater. Sci. Eng. $R$ 49, 1 (2005).

10. J.-W. Yoon, J.-H. Park, C.-C. Shur, and S.-B. Jung, $M i-$ croelectron. Eng. 84, 2552 (2007).

11. M. Alam, Y. Chan, and K. Tu, J. Appl. Phys. 94, 4108 (2003).

12. Y.M. Chow, W.M. Lau, and Z.S. Karim, Surf. Interface Anal. 31, 321 (2001).

13. J. Yu and J. Kim, Acta Mater. 56, 5514 (2008).

14. Y. Liu, J. Wang, L. Yin, P. Kondos, C. Parks, P. Borgesen, D. Henderson, E. Cotts, and N. Dimitrov, J. Appl. Electrochem. 38, 1695 (2008).

15. L. Yin, F. Wafula, N. Dimitrov, and P. Borgesen, J. Electron. Mater. 41, 302 (2012).

16. S. Kim and J. Yu, Mater. Lett. 106, 75 (2013).

17. S.-H. Kim and J. Yu, J. Mater. Res. 25, 1854 (2010).

18. W. Seo, K.-H. Kim, J.-H. Bang, M.-S. Kim, and S. Yoo, J. Electron. Mater. 43, 4457 (2014).

19. T.-K. Tsai and C.-G. Chao, Appl. Surf. Sci. 233, 180 (2004).

20. I. Baskaran, T.S. Narayanan, and A. Stephen, Mater. Chem. Phys. 99, 117 (2006).

21. T. Hentschel, D. Isheim, R. Kirchheim, F. Müller, and H. Kreye, Acta Mater. 48, 933 (2000).

22. S.C. Mehta, D.A. Smith, and U. Erb, Mater. Sci. Eng. A 204, 227 (1995).

23. R. Street and C. Tsai, Philos. Mag. B 57, 663 (1988).

24. Y.-C. Sohn and J. Yu, J. Mater. Res. 20, 1931 (2005).

25. Y. Tian, J. Chow, X. Liu, Y.P. Wu, and S.K. Sitaraman, J. Electron. Mater. 42, 230 (2013).

26. J.-W. Yoon, H.-S. Chun, H.-B. Kang, M.-H. Park, C.-W. Yang, M.-H. Park, C.-W. Yang, H.-J. Lee, and S.-B. Jung, Surf. Rev. Lett. 14, 827 (2007).

27. X.-C. Wang, W.-B. Cai, W.-J. Wang, H.-T. Liu, and Z.-Z. Yu, Surf. Coat. Technol. 168, 300 (2003).

28. Y.M. Chow, W.M. Lau, and Z.S. Karim, Surf. Interface Anal. 31, 321 (2001). 